Article

\title{
Sustainability Assessment of the New Residential Projects in the Baltic States: A Multiple Criteria Approach
}

\author{
Laura Tupenaite $^{1, *}$, Arturas Kaklauskas ${ }^{1}$, Irene Lill ${ }^{2}$ [D , Ineta Geipele ${ }^{3}$, Jurga Naimaviciene ${ }^{1}$, \\ Loreta Kanapeckiene ${ }^{1}$ and Linda Kauskale ${ }^{3}$ \\ 1 Department of Construction Management and Real Estate, Faculty of Civil Engineering, Vilnius Gediminas \\ Technical University, Saulètekio al. 11, LT-10223 Vilnius, Lithuania; arturas.kaklauskas@vgtu.lt (A.K.); \\ jurga.naimaviciene@vgtu.lt (J.N.); loreta.kanapeckiene@vgtu.lt (L.K.) \\ 2 Department of Civil Engineering and Architecture, School of Engineering, Tallinn University of Technology, \\ Ehitajate tee 5, 19086 Tallinn, Estonia; irene.lill@ttu.ee \\ 3 Institute of the Civil Engineering and Real Estate Economics, Department of Civil Construction and Real \\ Estate Economics and Management, Riga Technical University, 6 Kalnciema Str., LV-1048 Riga, Latvia; \\ ineta.geipele@rtu.lv (I.G.); linda.kauskale@rtu.lv (L.K.) \\ * Correspondence: laura.tupenaite@vgtu.lt; Tel.: +370-65-280-529
}

Received: 23 March 2018; Accepted: 25 April 2018; Published: 1 May 2018

\begin{abstract}
Housing is one of the most important public priorities affecting urban development and therefore has a significant impact on sustainable development. A housing project can be regarded as sustainable only when all the dimensions of sustainability (environmental, economic, and social) are dealt with. The aim of the present article is to propose an integrated, hierarchy-based, multiple-criteria approach for the sustainability assessment of new residential development projects, which is achieved through the accomplishment of three objectives. First, this paper proposes an original framework for a multiple-criteria assessment of new residential projects. Second, the proposed methodology is demonstrated in the assessment of nine residential development projects in Lithuania, Latvia, and Estonia according to a hierarchical system of 53 sustainability indicators developed specifically for the Baltic context. Finally, based on the research results, the paper proposes recommendations to stakeholders for enhancing the performance of new residential projects according to the principles of sustainability. The proposed sustainability assessment approach is not limited to the Baltic States and can also be used in other countries, applying the adapted sustainability assessment indicators.
\end{abstract}

Keywords: sustainability assessment; indicators; residential projects; multiple criteria approach; ranking; Baltic States

\section{Introduction}

Sustainable development is "development that meets the needs of the present without compromising the ability of future generations to meet their own needs" [1]. "Sustainability" and "sustainable development" in the literature and in practice are generally defined using an aggregate of characteristics, including economic security and growth, environmental quality and integrity, social cohesion and quality of life, and empowerment and governance [2].

Housing is one of the most basic human needs, a key component in the sustainable development of a community [3] and one of the most important public priorities affecting urban development. From an economic perspective, houses are among the major investments that people make in their lifetime [4]. However, from an environmental perspective, residential construction is one of the largest end users of environmental resources and one of the largest polluters of man-made and natural 
environments [5]. The housing sector in the European Union uses $40 \%$ of the total final energy consumed (of which heating and cooling accounts for around $70 \%$ ) and releases about $36 \%$ of the total $\mathrm{CO}_{2}$ emissions [6]. Therefore, common considerations regarding sustainable residential buildings include the use of environmentally friendly materials and water conservation, reduction of energy consumption, ensuring healthy and comfortable indoor and outdoor environments, reduction of pollution, cohesion of community, ensuring housing affordability, etc. Building sustainability involves various relations among built, natural, and social systems and comprises a complex of different priorities that require consideration.

It is believed that improvement in the performance of residential buildings with regard to social, economic, and environmental sustainability will encourage a greater sense of responsibility and place a greater value on the welfare of future generations. According to Mateus and Bragança [7] as well as Zhang et al. [8], the development and application of building sustainability measurements and benchmarking methods are solutions that promote a more sustainably built environment. Ding [5] argues that environmental building assessment methods significantly contribute to achieving the goal of sustainable development within construction.

Most authors agree that sustainability assessment is a multidimensional problem. For this purpose, various sustainability assessment indicators and frameworks have been formulated as a key approach to provide sustainability-related decision-making processes and have been widespread internationally [8]. According to Ali and Al Nsairat [9], LEED in the USA, BREEAM in the UK, CASBEE in Japan, and GBTool in Canada are the greenest building rating systems. However, these tools are often criticized for ignorance of economic and social aspects; moreover, the sustainability criteria in some of the tools are not prioritized for decision-making facilitation [10].

To prevent the abovementioned inadequacies, it is appropriate to use the multicriteria decision analysis (MCDA) methods, which allow for the combination of a variety of sustainability-indicator estimates into a single score. According to Ding [5], the development of a sustainability index is a way to address multiple criteria in relation to project decision making. The use of a sustainability index greatly simplifies the measurement of sustainability in terms of new residential projects.

By using MCDA methods, sustainability indicators of several buildings could be compared and the best performing alternative selected. Academics have developed numerous MCDA construction project evaluation methods, indicators and models for the assessment of sustainability. Some of the studies are dedicated to the assessment of residential projects. Ali and Al Nsairat [9] proposed the SABA Green Building Rating System in Jordan. The system defines the environmental, economic, and social aspects of sustainability. Assessment items are classified as a hierarchy with three levels: the category level, the indicator level, and the parameter level. A computer-based program is established to calculate the overall level of greenness of a particular building.

ALwaer and Clements-Croome [11] identified key issues related to sustainable intelligent buildings (environmental, social, economic, and technological factors), developed a conceptual model for the selection of the appropriate key performance indicators, and proposed a consensus-based model (Sustainable Built Environment Tool—SuBETool) for the sustainability assessment of intelligent buildings.

Mateus and Bragança [7] presented an innovative approach to the development of building-sustainability assessment and rating which contributes to the evolution of a generic methodology and an international understanding of sustainability dimensions. They proposed the $\mathrm{SBTool}{ }^{\mathrm{PT}}-\mathrm{H}$ to assess the sustainability of existing, new, and renovated residential buildings in urban areas, specifically in the Portuguese context. Mulliner et al. [12] assessed sustainable housing affordability with the multicriteria COmplex PRoportional ASsessment (COPRAS) method in three residential areas of Liverpool, United Kingdom. COPRAS was found to be an effective method for the assessment and, according to the authors, could be used in other regions or internationally. More recently, the authors have integrated the Analytic Hierarchy Process (AHP), the Technique 
for Order of Preference by Similarity to Ideal Solution (TOPSIS), and the COPRAS methods for the assessment of sustainable-housing affordability [13].

Yu et al. [14] proposed a multiple-criteria assessment method for green store buildings in China. The Expert Group Decision AHP method was used. The indicator system of the green store building rating included seven categories (landscape, energy efficiency, water efficiency, material and resources, indoor environment, construction management, and operation management).

Nilashi et al. [15] applied AHP and fuzzy logic for the development of a knowledge-based expert system to assess the performance level of a green building. The system is based on the assessment criteria of widespread building rating systems (GBI, BREEAM, LEED, and G Star).

Markelj et al. [16] offered the Simplified Method for Evaluating Building Sustainability (SMEBS). It is based on the model for building sustainability assessments and the acquired weights for parameters from the AHP and is intended as a tool to aid architects in the project planning phases.

Review of the academic research reveals that different sustainability indicators and systems are proposed for the sustainability assessment of residential projects in different countries. As noted by Mateus and Bragança [7], Ali and Al Nsairat [9], and Chandratilake and Dias [17], particular sustainability-assessment indicators, their significance, and tools are highly dependent on the environmental, social, and economic contexts of their use; therefore, different authors aim at developing national sustainability-assessment systems.

Developed countries, such as the United States, Japan, and the United Kingdom, are more conscious about environmental issues and pollution problems. They achieved significant progress in environmental management through developing sustainable practices and assessment tools [9]. On the other hand, transitional countries, such as the Baltic States, are still developing sustainability-assessment approaches. Therefore, studies in the context of the Baltic States are very limited. There are only a few studies that are worth mentioning.

In Lithuania, Viteikiene and Zavadskas [18] used the COPRAS method to rank residential areas according to the overall sustainability performance on 22 indicators related to sustainable development. More recently, Zavadskas et al. [19] assessed 21 neighborhoods in Vilnius, Lithuania, in the context of a healthy and safely built environment according to the principles of sustainable development. Different MCDA methods have been used for this purpose, including entropy and the Criterion Impact LOSs (CILOS) and Integrated Determination of Objective Criteria Weights (IDOCRIW) methods, to determine the objective weights of the criteria, while expert judgement has determined the subjective weights. With the overall weights determined, Vilnius neighborhoods have been assessed through the application of the COPRAS, Simple Additive Weighting (SAW), TOPSIS, and Evaluation based on Distance from Average Solution (EDAS) methods. The final results have then been processed using the rank average method, Borda count, and Copeland's method.

Nuuter et al. [20] used the COPRAS method for the comparison of housing-market sustainability in European countries, including Estonia, Lithuania, and Latvia. To perform an integrated analysis of housing-market sustainability, the Decision Support System for Housing Sustainability Assessment (DSS-HS) was developed. Six criteria groups (general economic, housing stock, housing affordability, population and social conditions, housing quality, and environmental quality) were used. The analysis of ranking and assessment results allowed making recommendations to increase housing-market sustainability.

Having analyzed the existing studies, it can be stated that most authors agree that sustainability assessment is a multidimensional problem, and therefore assessment frameworks and tools are usually based on the MCDA methodology. The application of MCDA methods for sustainability assessment of residential projects in the Baltic States is still very limited. To the best of the authors' knowledge, none of the previous studies presented and applied the sustainability-assessment framework for new residential projects in Lithuania, Latvia, and Estonia.

The present study continues the previous research performed by the authors [21] who classified, weighted, and ranked 53 sustainability indicators using the AHP approach for the specific Baltic context. 
The main aim of the current research is to propose an integrated, hierarchy-based, multiple-criteria framework for the sustainability assessment of new residential development projects. The proposed framework is demonstrated in real case study-assessment of nine residential projects in the capital cities of the Baltic States (Vilnius, Riga, and Tallinn). The authors also believe that the proposed sustainability-assessment approach is not limited to the Baltic context only and can be used in other countries that intend to follow the principles of sustainability in new residential developments. However, it should be noted that the hierarchy of indicators and their weights should be adapted to the specific context of a particular country.

\section{Methodology}

The development of the methodology for sustainability assessment of new residential projects is based on three assumptions:

1. The sustainability assessment should encompass an integrated evaluation of environmental, social, and economic indicators;

2. The system of indicators should conform to the local context of the country (in present research context of the Baltic States);

3. The sustainability assessment is a multidimensional problem that is solved using the multiple criteria method.

The proposed sustainability-assessment framework is presented in Figure 1.

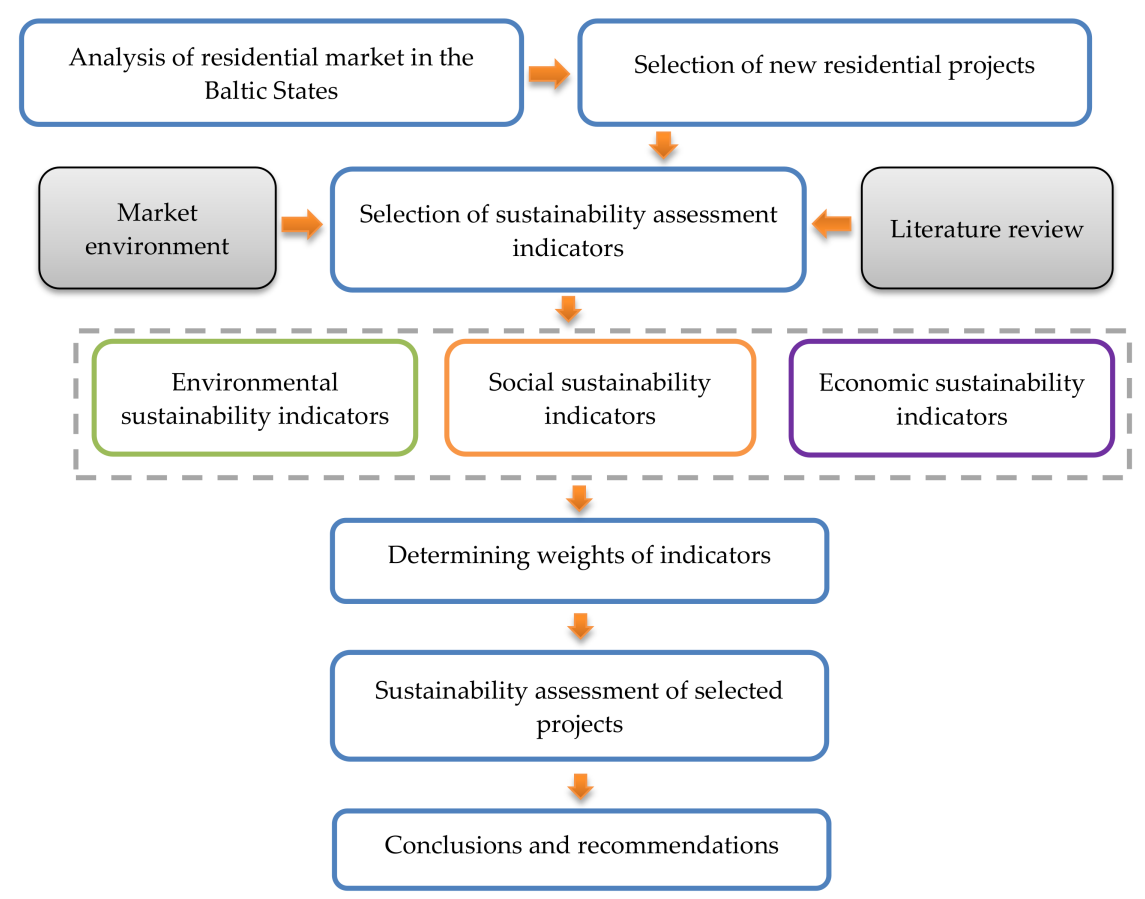

Figure 1. The sustainability-assessment framework for new residential projects.

According to the proposed framework, sustainability of new residential projects is assessed using five steps described as follows, using context of the Baltic States as an example.

Step 1. Analysis of the residential market in the Baltic States is performed, main trends are observed, and new residential developments identified. For further analysis, specific residential projects are selected.

Step 2. To assess the residential projects, an integrated system of sustainability indicators shall be developed. In the previous research [21], the authors proposed a hierarchically structured system of 
sustainability indicators to be used for the assessment of new residential development projects in the specific context of the Baltic States. The main indicators for the sustainability assessment were divided into three hierarchical levels: sustainability dimensions, categories, and indicators. Each category consists of several indicators, and a total of 53 indicators are addressed (see Section 3.3).

Step 3. Weighting of indicators was also performed in the previous research [21] by construction and real estate experts from the Baltic States (see Section 3.3 for weights of criteria). The multiple-criteria AHP approach was used for this purpose.

Step 4. To assess the sustainability of the selected residential projects, the appropriate multiple-criteria method should be used.

Alternatives can be assessed using various MCDA methods such as MAUT (Multi-Attribute Utility Theory), AHP, SAW, COPRAS, TOPSIS, ELECTRE, etc. An extensive review of the environmental applications of MCDA methods was performed by Huang et al. [22]. The authors identified over 300 papers published between 2000 and 2009 reporting on the use of MCDA in the environmental field. According to this study, MAUT, AHP, and ELECTRE were the most common methods in various environmental applications. More recently, approximately 3000 papers concerning MCDA in the environmental field have been identified by Cegan et al. [23]. The results show a linear growth in the share of MCDA papers in environmental science across all application areas. Moreover, results reveal that AHP/ANP and MAUT/MAVT are the most frequently mentioned MCDA methods in the literature. It has been noted, however, by Huang et al. [22] that MCDA approaches are similar enough and the selection of a particular method should be based more on "familiarity and available opportunities than solely on the merits of the different methods themselves".

The AHP method has already been used for the assessment of sustainability indicators [21]. However, it has been found out that this method is complicated and requires much effort and time to make pairwise comparisons. For this reason, the authors have decided to select a multiple-criteria method that is easier to apply with calculation results that can be clearly interpreted. Based on these assumptions, the SAW method has been chosen.

The SAW method was summarized by MacCrimmon in 1968 [24]. The method is a common aggregation method of MAUT for decision makers. It is the oldest, most widely known, and practically used method. The criterion of the method $S_{j}$ clearly demonstrates the main concept of multicriteria evaluation methods-the integration of the criteria values and weights into a single magnitude. This is also reflected in its name [25]. Calculations are performed as follows.

(1) Construction of the initial decision-making matrix:

$$
P=\left[\begin{array}{cccc}
x_{11} & x_{12} & \ldots & x_{1 n} \\
x_{21} & x_{22} & \ldots & x_{2 n} \\
\vdots & \vdots & \vdots & \vdots \\
x_{m 1} & x_{m 2} & \ldots & x_{m n}
\end{array}\right] ; i=\overline{1, m} ; j=\overline{1, n}
$$

where $n$ is the number of alternatives, $m$ is the number of attributes, and $x_{i j}$ is the attribute value of the $j$ th alternative. Here, the best values of each parameter are also determined according to the equations:

$$
\begin{aligned}
& x_{i}^{*}=\min _{i} x_{i j} ; \\
& x_{i}^{*}=\max _{i} x_{i j} .
\end{aligned}
$$

Equation (2) is used when a minimum of the $i$ th attribute is preferable, while Equation (3) is used when the maximum of the $i$ th attribute is preferable. 
(2) Performing normalization of the decision-making matrix. The normalized values of the decision-making matrix are calculated as follows:

$$
\begin{aligned}
\bar{x}_{i j} & =\frac{\min _{i} x_{i j}}{x_{i j}} ; \\
\bar{x}_{i j} & =\frac{x_{i j}}{\max _{i} x_{i j}} .
\end{aligned}
$$

Equation (4) is used when a minimum of the $i$ th attribute is preferable, while Equation (5) is used when the maximum of the $i$ th attribute is preferable.

(3) Defining efficiency criterion $S_{j}$ for each $j$ th alternative:

$$
S_{j}=\sum_{j=1}^{n} q_{i} \bar{x}_{i j}
$$

where $q_{i}$ is the weight of the $i$ th criterion.

(4) Ranking of alternatives in descending order.

Step 5. The multiple-criteria assessment of residential projects using the SAW method is performed for each level of criteria (categories and sustainability dimensions). Such assessment allows for identifying the most efficient residential projects in each category of sustainability dimensions and finally achieving a general assessment according to all dimensions. Based on rankings, the conclusions and recommendations are made to stakeholders for enhancing the performance of new residential projects according to the principles of sustainability.

The proposed sustainability assessment framework is further used in a real case study.

\section{Case Study: Sustainability Assessment of New Residential Projects in the Capital Cities of the Baltic States}

\subsection{Review of the Residential Market Developments in the Baltic States}

The enlargement of the European Union has influenced the development of the economy and the housing market in the Baltic States. Notably, in the period of 2004-2008, Lithuania as well as the other Baltic States enjoyed very strong economic growth. These countries were significantly influenced by favorable lending and expansion of private sector credit. Hence, the Baltic States experienced the most dramatic boom in housing prices globally over the last decade, which was followed by an economic downturn, and consequently, the burst of the price bubble. All three countries had experienced recession by 2009. However, in 2014 all three countries demonstrated housing market recovery and price growth. Lithuania had experienced double digit growth (10.9\%) since the period of crisis. Estonia did not fall far behind Lithuania, as it experienced growth of $8.4 \%$ in the housing market last year, while Latvia showed a healthy growth rate of 3.9\%.

As the real estate market in the Baltic States recovered, new residential developments were initiated. Current residential projects start to follow the general principles of sustainability while adapting the originality of buildings and aesthetics. It is understood that an integrated urban design as well as smart site planning is important for a residential project to merge well with a wider community and surrounding neighborhood.

During the period of 2012-2016, the number of transactions with regard to residential apartments remained almost the same in the Baltic States. Year by year, the number of transactions grew. Compared to 2012, in 2016 the number of residential-apartment transactions grew by $24 \%$ in Latvia, $33 \%$ in Estonia, and $46 \%$ in Lithuania. Since 2012, most transactions have been made in Lithuania. In 2016, in Lithuania, 30,585 transactions with residential apartments were made, which was 1.5 times higher than in Estonia $(20,722)$ and Latvia $(20,688)$ [26] (see Figure 2). 


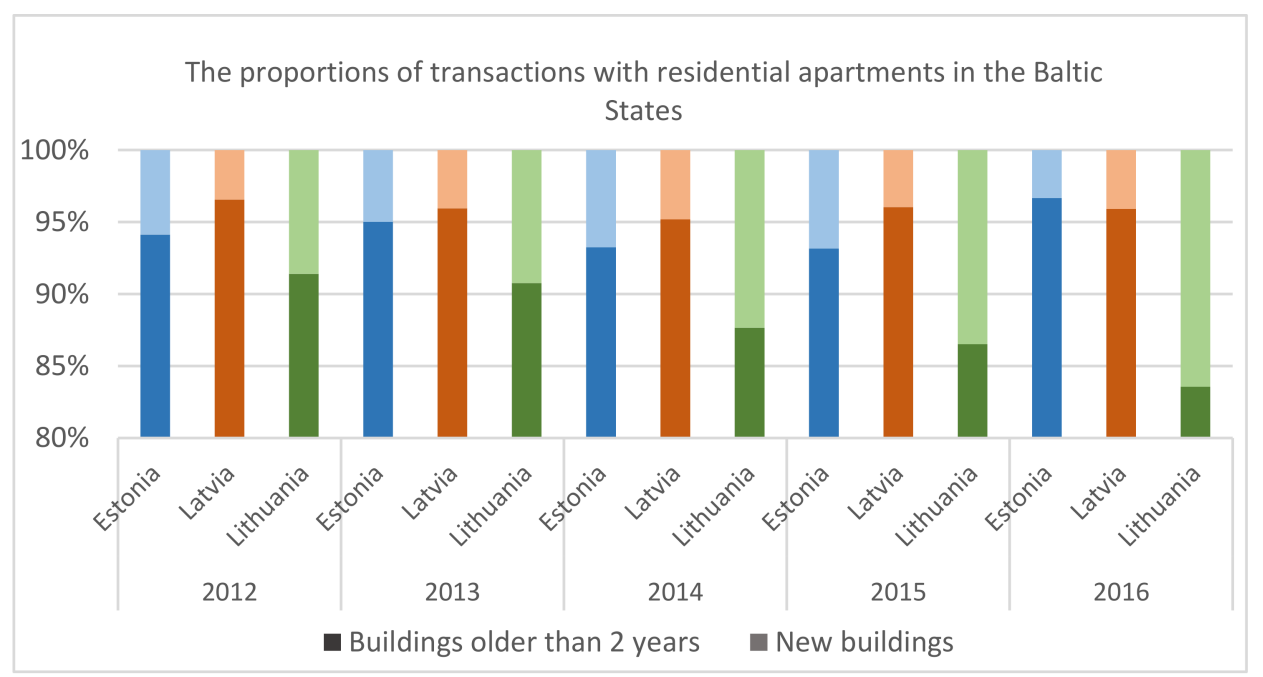

Figure 2. Transactions with residential apartments in the Baltic States [26].

Due to the large number of new projects, especially in Vilnius, the number of new apartment transactions is constantly increasing. In 2016, there were 5030 new apartment transactions made, which accounted for $19.7 \%$ of all transactions [26].

In Latvia and Estonia, the situation is different. Most transactions are made with apartments of the Soviet Union built serial-apartment blocks or pre-war buildings. Apartments in new projects account for only $3.5 \%-5 \%$ of all apartment transactions [26]. The residential housing stock in Estonia is also rather old. From 2012 to 2016, the proportion of new residential apartments out of all residential apartments was only 3\%-7\%. Most of the new apartments are sold in the capital, Tallinn [26].

Current trends reveal that higher competition in the residential market is observed in Lithuania, followed by Estonia and Latvia. It can be stated that all of the countries have new residential developments with clear indications of sustainability. Recent developments are usually low-energy-class buildings (i.e., A+ class is mandatory in Lithuania since 2018) with efficient heating systems and new interior and exterior design solutions, which are made from environmentally friendly materials.

\subsection{Multiple Criteria Sustainability Assessment of Residential Projects}

Nine new residential projects have been selected for the sustainability assessment-three projects from each capital of the Baltic States: Vilnius, Riga, and Tallinn (see Table 1).

Table 1. Description of the selected projects.

\begin{tabular}{lll}
\hline Žalgirio namai 135 \\
(Vilnius, Lithuania) \\
{$[27]$}
\end{tabular}


Table 1. Cont.

\begin{tabular}{lll}
\hline No. & \multicolumn{1}{c}{ Project } & \multicolumn{1}{c}{ Description } \\
(Vighthouse II & $\begin{array}{l}\text { A new multi-apartment residential building located in the Seskine } \\
\text { and Fabijoniskes neighborhoods has } 127 \text { apartments. In the } \\
\text { Lighthouse building, a "smart home" system has been installed for } \\
\text { the first time in Lithuania. This system was previously installed only } \\
\text { in individual dwellings. } \\
\text { All architectural solutions in this project followed the high energy } \\
\text { requirements of buildings and cost-effectiveness practices, so great } \\
\text { attention was paid to the balance between heat-saving and openness. } \\
\text { Windows with high thermal insulation properties were installed. } \\
\text { There is an enclosed patio area and an underground car park } \\
\text { monitored by IP cameras. } \\
\text { The newly constructed three-block building will have 264 spacious } \\
\text { apartments. A distinctive feature of the project is three leisure areas } \\
\text { on the roof of the building: a picnic area, a "green zone", and a } \\
\text { reading area. Energy class B. }\end{array}$ \\
\hline
\end{tabular}

Žvèryno namai

(Vilnius, Lithuania)

[29]

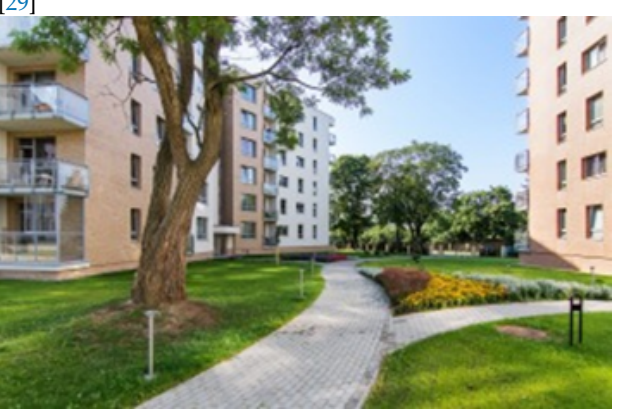

An apartment complex with 270 units underwent development in

Žverynas in one of the most beautiful and greenest areas of Vilnius, located between the Neris River and Vingis Park.

The development of this project puts the focus on nature conservation so only organic and environmentally friendly building materials were used. In order for the complex to be integrated into Žverynas landscape, the selected design has the Neris River bend-like form. Buildings are equipped with a "smart home" system and have a well-developed infrastructure. Energy class B.

\section{Domino}

(Riga, Latvia)

[30]

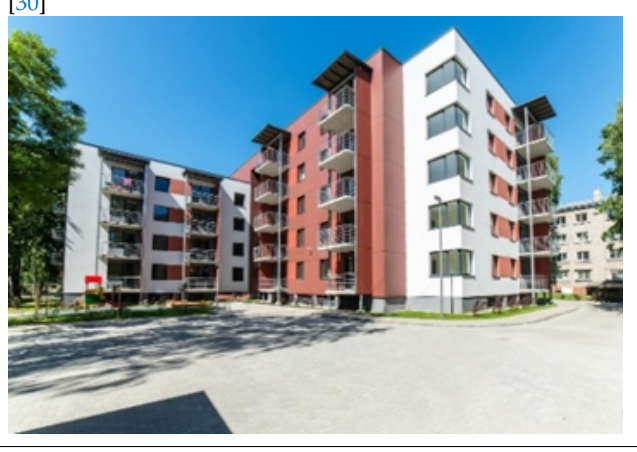

Miera Park House

(Riga, Latvia)

[31]

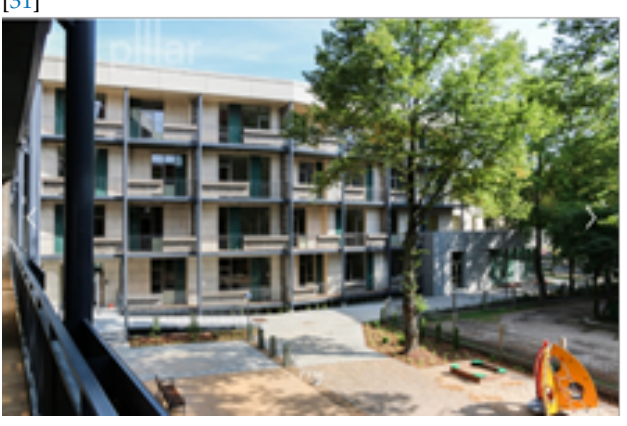

The Domino residential building is located in a quiet and calm area called Sampeteris, which is still relatively close to the city centre. It is one 4- to 5-storey residential building, which has 51 1-, 2-, 3- or 4-room apartments and an area of $36.8-112.2 \mathrm{~m}^{2}$. The property is well-lit and landscaped, and a playground has been installed. The trees were preserved and the property was additionally landscaped with shrubs. There is an opportunity to buy a parking place in the yard.

The project offers a comfortable and well-considered layout, combining aesthetic and functional features through the use of advanced technologies and high-quality materials for construction and interior decoration of the apartments. Energy class C.

Miera Park House is the name of an elite apartment building at Miera St. 57a in Riga. Miera Park House is one of a few Riga premium class apartment buildings constructed with the modern technology for higher life-standard demands. The complex has two buildings (five floors and four floors). Natural stone was used for the façade in combination with matte and translucent glass.

Apartments with an area ranging from $62 \mathrm{~m}^{2}$ up to $238 \mathrm{~m}^{2}$ are available. There are 38 apartments in total with 1 to 4 rooms. All of the apartments and spacious balconies are located on the sunny south side, while the hallways, stairs, and elevators are on the north side of the building.

Apartments are offered according to three full finishing levels, with the new tenants able to choose one of the options prepared by the designer. Apartments are fitted with high-quality kitchen equipment and all necessary appliances. Spacious underground parking for 50 cars is available. Storage spaces are available in the basement of the building.

The property $\left(3811 \mathrm{~m}^{2}\right)$ is fenced, landscaped, well-lit, and secure. The yard is situated between the two buildings and has trees and shrubs, a children's playground, and benches. The landscaped roof terrace with sauna complex is available to ensure the comfort of tenants. Energy class $C$. 
Table 1. Cont.

\begin{tabular}{ll}
\hline No. & \multicolumn{1}{c}{ Project } \\
\hline & $\begin{array}{l}\text { Felicity Apartments } \\
\text { (Riga, Latvia) } \\
\text { [32] }\end{array}$ \\
& \\
&
\end{tabular}

Noblessner Home Port (Tallinn, Estonia)

[33]

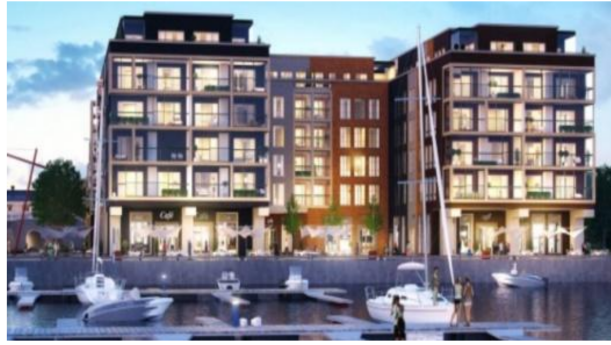

Vibu 2/4

(Tallinn, Estonia)

[34]

A8

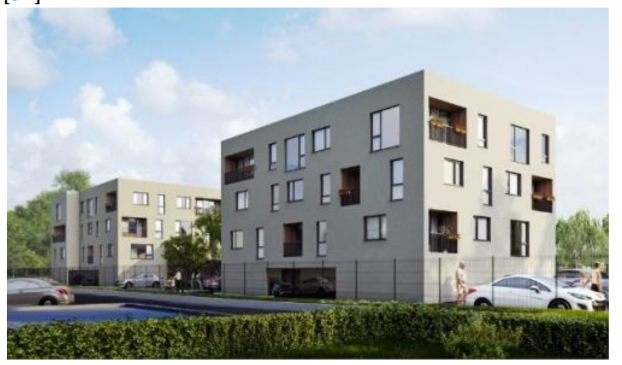

Felicity Apartments is a seven-storey modern building. The building offers 62 comfortable (1-, 2-, 3- and 4-room) apartments of 35-101 m². Apartments fully correspond to modern functional requirements and are designed using sound and rational planning. The apartments are fully finished and come equipped with energy-saving solutions, underground parking, and storage spaces.

Most of the apartments have French balconies, while the apartments on the upper floors have terraces with beautiful views of the city towers. In turn, three apartments on the first floor come with a spacious garden terrace with a private backyard. Each apartment has its own water and heat meter that can be remotely read by the house manager.

The apartment building is located in the historical center, close to parks, and only a few minutes away from the Old Town.

Felicity Apartments is the first residential building in the Baltic States which has been granted the BREEAM international sustainable building certificate. Energy class B.

The Noblessner Home Port (Kodusadam) development encompasses a total of 4 buildings that will have 208 apartments and close to $3700 \mathrm{~m}^{2}$ of office and retail space. At the first stage, a 6-storey, 66-unit apartment building will be built right on the seafront, along with a 279-space underground garage. Due to their seaside location and views, the exclusive commercial spaces planned for the ground floor of the Staapli 4 apartment building are perfect for restaurants and cafes as well as companies that are willing to capitalize on a seaside ambience. The second stage will consist of 3 apartment buildings at Staapli 3, 8, and 12 .

Noblessner is a unique residential development project where modern-quality apartments meet a historical environment.

This integral development is centered on the people living there-cars will be moved to an underground level, the interior courtyards have private play and recreational areas, and the buildings are surrounded by paths meant for pedestrians, an open plaza area, and promenade. The seaside apartments are spacious with ample light, high energy efficiency, a good interior climate, and cozy floor heating. All apartments have glass-enclosed balconies, and some apartments have a sauna and readiness for a fireplace.

Design management was performed through the use of an integrated BIM mode. In addition, building information modeling was used to calculate construction quantities, arrange procurements, plan work, prepare $4 \mathrm{D}$ schedules, draw up the budget, and prepare visualizations. Energy class B.

The Sea Gate residential development is located near the Seaplane Harbour close to Kalamaja Park. Vibu 2 and 4 are located in a historically stately and picturesque area of the Kalamaja milieu. The project is distinguished by tasteful and modern Scandinavian architecture and thoughtful room layouts.

The Sea Gate development project is composed of five four-storey buildings with a single stairwell. Buildings are situated between the recreation areas, children's playground, and private courtyards. Buildings are connected with underground parking. Underground parking can be accessed from all buildings. Each staircase is served by a spacious elevator. Each apartment has a storage room, which is located on the parking floor of the buildings.

The Vibu 2 and 4 project has a total of 53 (apartments 1-25 at Vibu 2 and apartments 26-53 at Vibu 4) 1- to 4-room apartments with an are of $26.8-123.4 \mathrm{~m}^{2}$. The apartments have glazed balconies and fenced terraces on the ground floors.

$A$ " $B$ " building energy performance certificate has been issued. The building is designed for floor heating, and heat supply is provided by central heating. The house has an apartment-based heat recovery ventilation system. In addition, separate extraction equipment from the staircase, storage rooms, and kitchen equipmen are planned. 
Table 1. Cont.

\begin{tabular}{|c|c|c|}
\hline No. & Project & Description \\
\hline A9 & $\begin{array}{l}\text { Meerhof } 2.0 \\
\text { (Tallinn, Estonia) } \\
\text { [35] }\end{array}$ & $\begin{array}{l}\text { The building at Pirita tee } 26 \text { is a 9-storey apartment building that } \\
\text { houses } 73 \text { apartments with } 2 \text { underground levels with a car park for } \\
101 \text { cars. Net area: } 10,800 \mathrm{~m}^{2} \text { in total. It is located on the eastern shore } \\
\text { of the Bay of Tallinn, overlooking downtown Tallinn. The Meerhof } \\
\text { complex consists of the exclusive apartment building constructed in } \\
2015 \text { and } 2 \text { separate towers being built at Pirita tee } 20 \mathrm{a} \text {, which are } \\
\text { connected to each other by an underground car park to ensure } \\
\text { convenient parking irrespective of the weather. A private rest, sports, } \\
\text { and green area with a children's playground is located between } \\
\text { the towers. } \\
\text { Functional interior plans have primarily been used as the basis for } \\
\text { designing the building. The selected materials are deliberately } \\
\text { exclusive. A stepped landscaping fitting in with the waved line of the } \\
\text { planned balconies has been designed in front of the car park planned } \\
\text { between the buildings. } \\
\text { The lighting in the area in front of the entrances has been thought } \\
\text { through and the paving is covered with burnt granite tiles. } \\
\text { The façades facing the Song Festival Grounds are covered with } \\
\text { high-quality composite tiles. The } 10 \text { th floor has a partial step back } \\
\text { and larger terraces than the others. } \\
\text { The architect of the building is Tormi Sooväli; the interior design was } \\
\text { done by Riina Harik and Külli Salum, interior designers from SAHA } \\
\text { IN. Energy class B. }\end{array}$ \\
\hline
\end{tabular}

The selected projects have been assessed by the hierarchical system of sustainability criteria taken from the previous research conducted by the authors [21] (see Figure 3). A description of criteria is presented in Table S1 of the Supplementary Materials.

Following the SAW methodology, an initial decision-making matrix (Equation (1)) was formed (see Table 2). Quantitative indicators were estimated from available statistical resources, databases of national registers, crime, noise maps, etc. Qualitative indicators have been estimated by a group of 10 experts from Lithuania, Latvia, and Estonia. Site visits have been performed, discussions through the use of digital technologies organized, and final assessments by points obtained.

In the second step, the initial decision making-matrix has been normalized (Equations (4) and (5)), weighted through the use of significances of indicators from the previous research [21] (see Figure 3 and Table S2 in Supplementary Materials), and finally, efficiency indexes in each category and dimension obtained by Equation (6) (see Tables S3-S4 in the Supplementary Materials for detailed calculations). Based on the indexes, project alternatives have been ranked. 


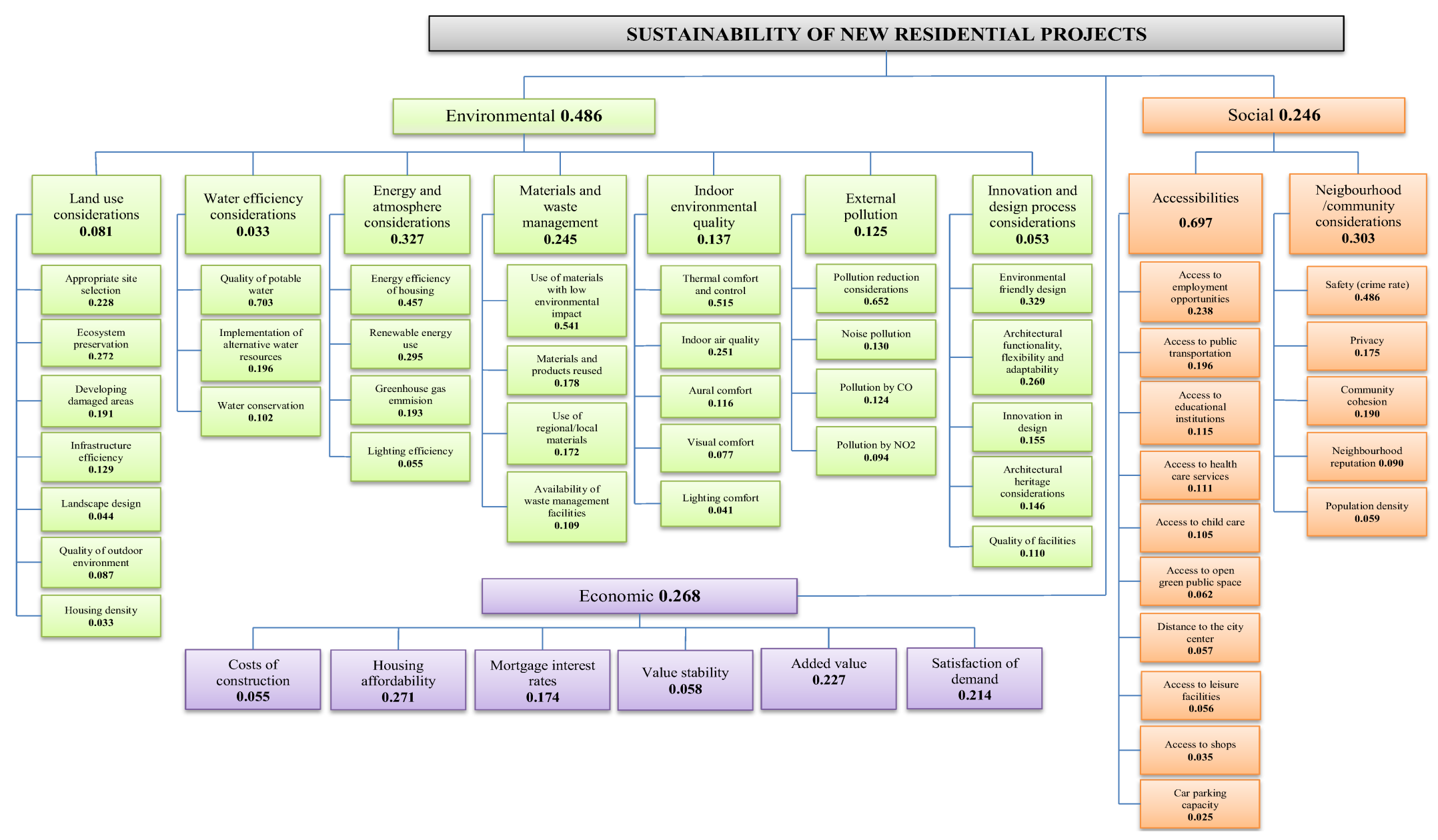

Figure 3. Hierarchical structure of sustainability indicators and their weights [21]. 
Table 2. Initial decision-making matrix.

\begin{tabular}{|c|c|c|c|c|c|c|c|c|c|c|c|}
\hline \multirow{2}{*}{ Category } & \multirow{2}{*}{ Unit of Measurement } & \multirow{2}{*}{ Indicators } & \multicolumn{3}{|c|}{ LITHUANIA } & \multicolumn{3}{|c|}{ LATVIA } & \multicolumn{3}{|c|}{ ESTONIA } \\
\hline & & & A1 & A2 & A3 & A4 & A5 & A6 & A7 & A8 & A9 \\
\hline \multicolumn{12}{|c|}{ Environmental sustainability dimension } \\
\hline \multirow{7}{*}{ Land use considerations } & Points & Appropriate site selection & 8 & 6 & 8 & 6 & 7 & 8 & 9 & 9 & 8 \\
\hline & Points & Developing damaged areas & 8 & 4 & 4 & 4 & 6 & 6 & 10 & 4 & 4 \\
\hline & Points & Landscape design & 5 & 7 & 9 & 5 & 7 & 7 & 10 & 7 & 9 \\
\hline & Points & Ecosystem preservation & 2 & 3 & 8 & 3 & 5 & 6 & 8 & 5 & 9 \\
\hline & Points & Quality of outdoor environment & 5 & 7 & 8 & 5 & 7 & 7 & 10 & 8 & 9 \\
\hline & Number, $\mathrm{km}^{2}$ & Housing density & 56.09 & 42.2 & 72.59 & 125 & 69.5 & 56.6 & 56.2 & 48.9 & 68.22 \\
\hline & Points & Infrastructure efficiency & 10 & 8 & 9 & 7 & 7 & 8 & 10 & 8 & 9 \\
\hline \multirow{3}{*}{$\begin{array}{l}\text { Water efficiency } \\
\text { considerations }\end{array}$} & Points & Quality of potable water & 9 & 8 & 10 & 9 & 9 & 10 & 9 & 10 & 10 \\
\hline & Points & Implementation of alternative water resources & 1 & 1 & 1 & 2 & 2 & 2 & 1 & 1 & 1 \\
\hline & Points & Water conservation & 1 & 1 & 1 & 3 & 5 & 5 & 1 & 1 & 1 \\
\hline \multirow{4}{*}{$\begin{array}{l}\text { Energy and atmosphere } \\
\text { considerations }\end{array}$} & Points & Energy efficiency of housing & 4 & 3 & 3 & 2 & 2 & 3 & 3 & 3 & 3 \\
\hline & Points & Lighting efficiency & 5 & 9 & 7 & 5 & 5 & 9 & 8 & 8 & 9 \\
\hline & Points & Renewable energy use & 8 & 1 & 1 & 1 & 2 & 1 & 1 & 1 & 10 \\
\hline & Tons/year & Greenhouse gas emission & 25.92 & 38.72 & 30.09 & 47.6 & 47.6 & 38.5 & 39.5 & 30.2 & 32.9 \\
\hline \multirow{4}{*}{$\begin{array}{l}\text { Materials and waste } \\
\text { management }\end{array}$} & Points & Use of materials with low environmental impact & 7 & 6 & 9 & 6 & 7 & 8 & 8 & 8 & 9 \\
\hline & Points & Use of regional/local materials & 50 & 65 & 60 & 50 & 45 & 72 & 50 & 60 & 70 \\
\hline & Points & Materials and products reused & 10 & 10 & 15 & 10 & 10 & 20 & 13 & 20 & 20 \\
\hline & Points & Availability of waste management facilities & 9 & 9 & 9 & 7 & 8 & 9 & 9 & 10 & 9 \\
\hline \multirow{5}{*}{$\begin{array}{l}\text { Indoor environmental } \\
\text { quality }\end{array}$} & Points & Thermal comfort and control & 9 & 10 & 8 & 8 & 8 & 9 & 8 & 8 & 9 \\
\hline & Points & Indoor air quality (IAQ) solutions & 9 & 7 & 8 & 8 & 7 & 7 & 8 & 8 & 9 \\
\hline & Points & Lighting comfort & 7 & 9 & 8 & 9 & 8 & 8 & 9 & 9 & 10 \\
\hline & Points & Visual comfort & 5 & 7 & 8 & 8 & 8 & 9.00 & 10 & 7 & 10 \\
\hline & Points & Aural comfort & 10 & 8 & 8 & 7.00 & 8.00 & 8.00 & 9 & 9 & 10 \\
\hline \multirow{4}{*}{ External pollution } & $\mu \mathrm{g} / \mathrm{m}^{3}$ & Pollution by NO2 & 25 & 18.4 & 23.92 & 35 & 60 & 60 & 21 & 18.3 & 14.3 \\
\hline & $\mu \mathrm{g} / \mathrm{m}^{3}$ & Pollution by $\mathrm{CO}$ & 0.34 & 0.26 & 0.3 & 0.29 & 0.3 & 0.3 & 0.45 & 0.36 & 0.65 \\
\hline & $\mathrm{dB}$ & Noise pollution & 41.56 & 62.93 & 49.17 & 62 & 75 & 67 & 58.23 & 32.3 & 44.2 \\
\hline & Points & Pollution reduction considerations & 4 & 6 & 7 & 6 & 6 & 6 & 8 & 7 & 9 \\
\hline \multirow{5}{*}{$\begin{array}{l}\text { Innovation and design } \\
\text { process considerations }\end{array}$} & Points & Innovation in design & 7 & 10 & 8 & 6 & 7 & 8 & 9 & 9 & 9 \\
\hline & Points & Environmentally friendly design & 6 & 7 & 8 & 7 & 8 & 9 & 9 & 8 & 10 \\
\hline & Points & Quality of facilities/equipment & 8 & 8 & 8 & 7 & 9 & 9 & 9 & 8 & 10 \\
\hline & Points & Architectural heritage considerations & 5 & 6 & 7 & 8 & 8 & 8 & 10 & 8 & 8 \\
\hline & Points & Architectural functionality, flexibility, and adaptability & 8 & 8 & 9 & 7 & 9 & 8 & 9 & 8 & 10 \\
\hline
\end{tabular}


Table 2. Cont.

\begin{tabular}{|c|c|c|c|c|c|c|c|c|c|c|c|}
\hline \multirow{2}{*}{ Category } & \multirow{2}{*}{ Unit of Measurement } & \multirow{2}{*}{ Indicators } & \multicolumn{3}{|c|}{ LITHUANIA } & \multicolumn{3}{|c|}{ LATVIA } & \multicolumn{3}{|c|}{ ESTONIA } \\
\hline & & & A1 & A2 & A3 & A4 & A5 & A6 & A7 & A8 & A9 \\
\hline \multicolumn{12}{|c|}{ Social sustainability dimension } \\
\hline \multirow{10}{*}{ Accessibilities } & $\mathrm{km}$ & Distance to the city centre & 2 & 5.4 & 1.2 & 8 & 3 & 3.2 & 2.6 & 11 & 6.2 \\
\hline & $\mathrm{m}$ & Access to public transportation & 240 & 350 & 150 & 400 & 2000 & 400 & 200 & 120 & 100 \\
\hline & Number per 1000 residents & Access to employment opportunities & 21.5 & 9.3 & 10.4 & 4.6 & 4.6 & 4.8 & 8.1 & 9.2 & 9.9 \\
\hline & $\mathrm{m}$ & Access to educational institutions & 330 & 300 & 850 & 1800 & 2000 & 900 & 800 & 600 & 560 \\
\hline & $\mathrm{m}$ & Access to shops & 490 & 350 & 450 & 150 & 650 & 350 & 300 & 200 & 320 \\
\hline & $\mathrm{m}$ & Access to health care services & 450 & 1200 & 1050 & 2800 & 47 & 2300 & 400 & 500 & 250 \\
\hline & $\mathrm{m}$ & Access to child care & 320 & 300 & 650 & 200 & 800 & 4 & 350 & 300 & 260 \\
\hline & $\mathrm{m}$ & Access to leisure facilities & 950 & 350 & 200 & 200 & 200 & 200 & 120 & 50 & 140 \\
\hline & $\mathrm{m}$ & Access to open green public space & 350 & 10 & 10 & 150 & 200 & 200 & 40 & 20 & 50 \\
\hline & Number of cars & Car parking capacity & 40 & 30 & 10 & 50 & 40 & 50 & 50 & 56 & 101 \\
\hline \multirow{5}{*}{$\begin{array}{l}\text { Neighborhood/community } \\
\text { considerations }\end{array}$} & Crime rate per 1000 residents & Safety (crime rate) & 13.95 & 6.26 & 7.22 & 12 & 15 & 9 & 4.2 & 5.8 & 10.2 \\
\hline & Points & Neighborhood reputation & 9 & 6 & 10 & 5 & 7 & 7 & 10 & 8 & 8 \\
\hline & Number of residents per $\mathrm{km}^{2}$ & Population density & 4917.31 & 9697.32 & 4103.33 & 2117 & 2117 & 2117 & 3820.22 & 4589.33 & 3890.36 \\
\hline & Points & Community cohesion & 6 & 9 & 8 & 4 & 4 & 7 & 8 & 8 & 7 \\
\hline & Points & Privacy & 8 & 6 & 6 & 6 & 9 & 7 & 8 & 7 & 8 \\
\hline \multicolumn{12}{|c|}{ Economic sustainability dimension } \\
\hline & $\mathrm{EUR} / \mathrm{m}^{2}$ & Price of the apartment & 1689 & 1530 & 1850 & 1142 & 1773 & 1909 & 3012 & 2560 & 3348 \\
\hline & Number & Housing affordability & 2.6 & 2.36 & 2.85 & 2.34 & 3.21 & 4.27 & 2.47 & 2.1 & 2.74 \\
\hline & Percentage & Mortgage interest rates & 2.8 & 2.5 & 2.8 & 2.7 & 2.7 & 2.7 & 3.2 & 2.8 & 2.5 \\
\hline & Percentage & Value stability & 85 & 50 & 80 & 85 & 85 & 85 & 90 & 90 & 85 \\
\hline & Points & Added value & 9 & 7 & 8 & 8 & 6 & 7 & 10 & 8 & 9 \\
\hline & Percentage & Satisfaction of demand & 100 & 93 & 82 & 94 & 41 & 50 & 100 & 90 & 75 \\
\hline
\end{tabular}


The environmental-sustainability dimension is the most extensive one and includes seven categories of sustainability indicators. Efficiency indexes obtained by the SAW method and rankings are presented in Table 3.

Table 3. Ranking of alternatives in the environmental-sustainability dimension.

\begin{tabular}{|c|c|c|c|c|c|c|c|c|c|}
\hline Category & A1 & A2 & A3 & A4 & A5 & A6 & A7 & A8 & A9 \\
\hline \multicolumn{10}{|c|}{ Land use considerations } \\
\hline Index & 0.629 & 0.530 & 0.779 & 0.361 & 0.474 & 0.516 & 0.721 & 0.452 & 0.615 \\
\hline Rank & 3 & 5 & 1 & 9 & 8 & 6 & 2 & 7 & 4 \\
\hline \multicolumn{10}{|c|}{ Water efficiency considerations } \\
\hline Index & 0.751 & 0.680 & 0.821 & 0.889 & 0.930 & 1.000 & 0.751 & 0.821 & 0.821 \\
\hline Rank & 5 & 6 & 4 & 3 & 2 & 1 & 5 & 4 & 4 \\
\hline \multicolumn{10}{|c|}{ Energy and atmosphere considerations } \\
\hline Index & 0.917 & 0.556 & 0.581 & 0.394 & 0.423 & 0.557 & 0.548 & 0.587 & 0.845 \\
\hline Rank & 1 & 6 & 4 & 9 & 8 & 5 & 7 & 3 & 2 \\
\hline \multicolumn{10}{|c|}{ Materials and waste management } \\
\hline Index & 0.727 & 0.703 & 0.916 & 0.645 & 0.704 & 0.929 & 0.814 & 0.911 & 0.984 \\
\hline Rank & 6 & 8 & 3 & 9 & 7 & 2 & 5 & 4 & 1 \\
\hline \multicolumn{10}{|c|}{ Indoor environmental quality } \\
\hline Index & 0.898 & 0.894 & 0.822 & 0.815 & 0.794 & 0.854 & 0.853 & 0.830 & 0.949 \\
\hline Rank & 2 & 3 & 7 & 8 & 9 & 4 & 5 & 6 & 1 \\
\hline \multicolumn{10}{|c|}{ External pollution } \\
\hline Index & 0.539 & 0.698 & 0.756 & 0.652 & 0.621 & 0.627 & 0.787 & 0.800 & 0.891 \\
\hline Rank & 9 & 5 & 4 & 6 & 8 & 7 & 3 & 2 & 1 \\
\hline \multicolumn{10}{|c|}{ Innovation and design process considerations } \\
\hline Index & 0.675 & 0.769 & 0.811 & 0.699 & 0.822 & 0.844 & 0.915 & 0.816 & 0.955 \\
\hline Rank & 9 & 7 & 6 & 8 & 4 & 3 & 2 & 5 & 1 \\
\hline
\end{tabular}

It can be observed that all of the projects have strengths and weaknesses in different categories of the sustainability dimension. The "Land use considerations" category includes seven indicators, namely "appropriate site selection", "developing damaged areas", "landscape design", "ecosystem preservation", "quality of outdoor environment", "housing density", and "infrastructure efficiency". "Appropriate site selection" ( $q=0.228)$ and "ecosystem preservation" $(q=0.272)$ have the highest influence on rankings. According to the results of the multiple-criteria assessment, project alternative A3 is ranked as the best in this category mostly due to its favorable location (one of the most beautiful and greenest areas of Vilnius) and focus on nature conservation.

The category "Water efficiency considerations" includes "quality of potable water" and strategies ("reuse of rain and grey water" and "water conservation") that have a significant impact on reducing overall water consumption. "Quality of potable water" $(q=0.703)$ has highest influence on rankings. In general, rankings of the projects are very similar because water resources are sufficient in the Baltic States and potable water, in general, is of good quality. The highest rank is given to Latvian project A6 as it includes some strategies on the reuse of rain and grey water and water conservation. These strategies were not included in residential development projects of Lithuania and Estonia.

The category "Energy and atmosphere considerations" includes "energy efficiency of housing" (determined by energy class), "lighting efficiency", "renewable energy use", and "greenhouse gas emission". "Energy efficiency of housing" ( $q=0.457)$ and "renewable energy use" $(q=0.295)$ have the highest influence on rankings. There was only one project from Lithuania (A1) that had an " $A$ " energy class, equipped with heat recovery ventilation system; it was ranked as the best in this category.

To enhance the energy efficient design of the buildings, the selection of appropriate materials is vitally important and, therefore, should be considered. The "Materials and waste management" category includes four indicators, namely, "use of materials with low environmental impact", "use of local/regional materials", "materials and products reused", and "availability of waste management 
facilities". "Use of materials with low environmental impact" $(q=0.541)$ has the highest influence on rankings. Project A9 from Estonia was ranked as the best according to a majority of indicators as a modern Scandinavian-style residential development. Moreover, it is noteworthy to mention that Latvian project A6 takes second place as the first residential building in the Baltic States which has been granted a BREEAM international sustainable building certificate.

The "Indoor environmental quality" category includes five indicators on thermal, aural, visual, lighting comfort, and indoor air quality. "Thermal comfort and control" $(q=0.515)$ has the highest influence on rankings, as heating efficiency is extremely important for the climate of the Baltic States. It can be observed that all of the projects received high efficiency indexes. The first in this category is Estonian project A9 due to its unique and comfortable indoor design. A smart house solution is integrated into all the apartments at Meerhof 2.0. This enables the heating, cooling, and ventilation in the rooms to be managed, and heat, water, and electricity consumption can be tracked from a smart device [35].

The category "External pollution" has been assessed using four indicators, including pollution by $\mathrm{NO}_{2}$ and $\mathrm{CO}$, noise pollution, and pollution reduction considerations available in the new residential project. The latter indicator had the highest influence on general ranking $(q=0.652)$. All of the projects have received high efficiency indexes. The highest-ranked project is A9 due to its favorable location (in the seaside area of Tallinn, $150 \mathrm{~m}$ from the seaside promenade) and innovative design solutions for noise protection. To reduce noise impact, special insulation tiles were installed on the hollow-core slabs of all the ceilings. To ensure residents' well-being, in the walls between apartments and those between the apartments and public areas, the level of airborne noise soundproofing is $60 \mathrm{~dB}$ (the required standard is $55 \mathrm{~dB}$ ). Double high-strength gypsum board was used in the interior layers of the outer walls. The gap around the building windows and entry doors of the apartments were hermetically sealed with mastic [35].

All of the residential projects are newly developed and, therefore, include innovative design solutions. Five indicators for "Innovation and design process considerations" have been assessed to rank the projects, namely "innovation in design", "environmentally friendly design", "quality of facilities", "architectural heritage considerations", and "architectural functionality, flexibility, and adaptability". "Environmentally friendly design" $(q=0.329)$ has the highest influence on the rankings. The highest rank has been received by Estonian project A9. Meerhof 2.0 is among the highest quality and most innovative new residential developments in Estonia designed by famous architect Tormi Sooväli, who has over 20 years of planning experience. To achieve a perfect result, experts in acoustics, energy efficiency, and even feng shui were included in the design team. The first floors, which step back from the general volume of the building, are covered with a specially designed glass façade and the main entrances of the building have been highlighted with a portal lined with black granite. A stepped landscaping fitting in with the waved line of the planned balconies has been designed in front of the car park planned between the buildings. All of the apartments are equipped with smart house solutions. Solar panels will be installed on the roof of the building [35].

Figure 4 depicts the efficiency indexes of the projects in the environmental-sustainability dimension. The "Energy and atmosphere considerations" $(q=0.327)$ and "Materials and waste management" $(q=0.245)$ categories have the highest influence on rankings. It can be observed that according to all environmental sustainability categories, the highest-ranked projects are A9, A1, and A3. These projects are the most environmentally friendly, encompass modern energy saving solutions, have an innovative and environmentally friendly design, and are located in a favorable environment within the developed infrastructure. 


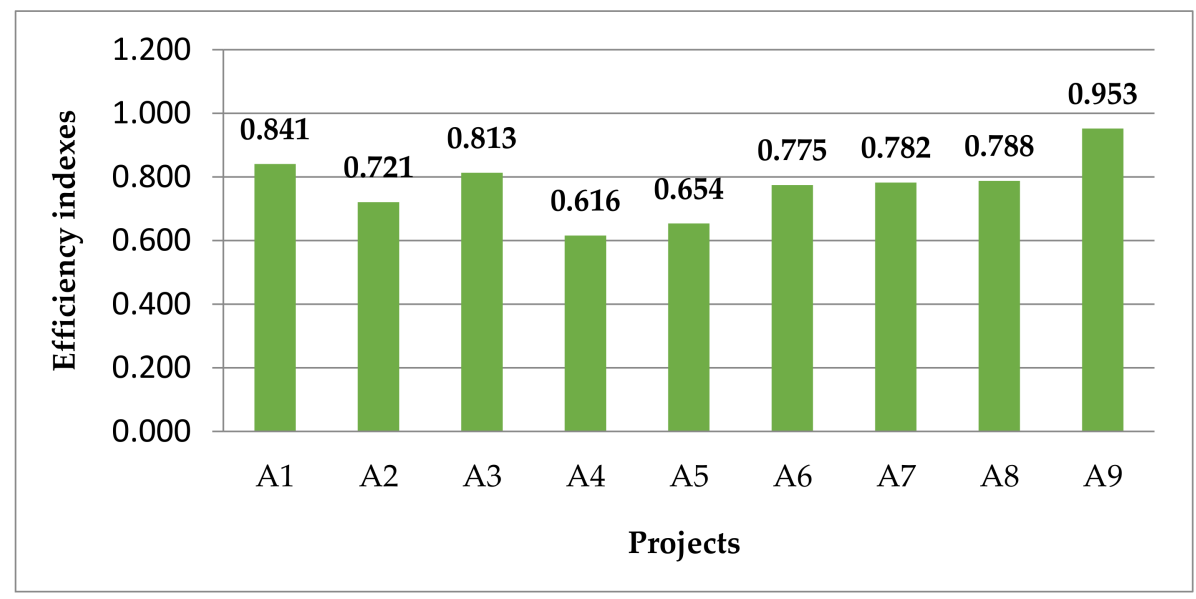

Figure 4. Efficiency of the residential projects in the environmental-sustainability dimension.

The social-sustainability dimension has been divided into two categories, namely "accessibilities" and "neighborhood/community considerations". Efficiency indexes obtained by the SAW method and rankings are presented in Table 4.

Table 4. Ranking of alternatives in the social-sustainability dimension.

\begin{tabular}{|c|c|c|c|c|c|c|c|c|c|}
\hline Category & A1 & A2 & A3 & A4 & A5 & A6 & A7 & A8 & A9 \\
\hline \multicolumn{10}{|c|}{ Accessibilities } \\
\hline Index & 0.497 & 0.385 & 0.439 & 0.197 & 0.247 & 0.314 & 0.340 & 0.468 & 0.475 \\
\hline Rank & 1 & 5 & 4 & 9 & 8 & 7 & 6 & 3 & 2 \\
\hline \multicolumn{10}{|c|}{ Neighborhood/community considerations } \\
\hline Index & 0.535 & 0.700 & 0.689 & 0.475 & 0.518 & 0.633 & 0.933 & 0.756 & 0.608 \\
\hline Rank & 7 & 5 & 2 & 9 & 8 & 6 & 1 & 4 & 3 \\
\hline
\end{tabular}

In the "Accessibilities" category, 10 indicators have been distinguished, including access to public transportation, urban amenities, and employment opportunities. "Access to employment opportunities" ( $q=0.238)$ has the highest influence on rankings. Due to its very favorable location (the center of Vilnius with all necessary infrastructure and highest employment opportunities), project A1 has been ranked as the best one in this category.

Different efficiency indexes have been obtained in the "Neighborhood/community considerations" category, which includes five indicators: "safety", "neighborhood reputation", "community cohesion", "population density in living area", and "privacy". "Safety" (crime rate) has the highest $(q=0.486)$ influence on rankings. Project A7 (a 6-storey, 66-unit apartment building that will be built right on the seafront) in the prestigious area of Tallinn has received the highest ranking in this category.

Figure 5 depicts the efficiency indexes of the projects in the social-sustainability dimension. It can be observed that according to both social-sustainability categories, the highest-ranked projects are A8, A1, and A9. These projects are located in prestigious districts with highly developed infrastructure. It is noteworthy that in general ranking, higher significance is given to "accessibilities" $(q=0.697)$; therefore, projects with better access to local amenities have been ranked higher. 


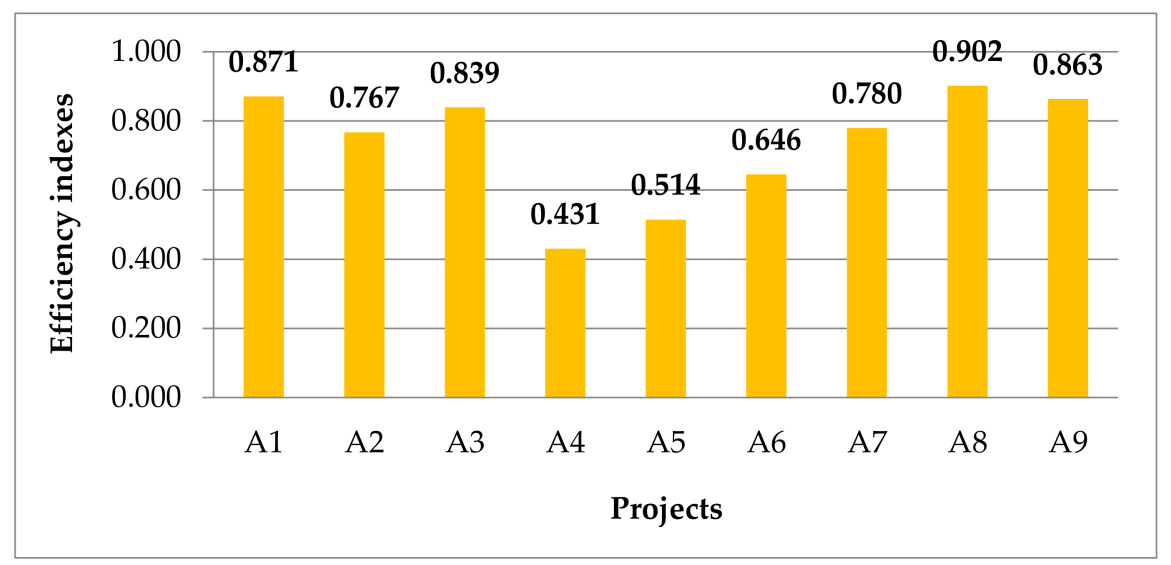

Figure 5. Efficiency of the residential projects in the social-sustainability dimension.

The economic-sustainability dimension includes six economic indicators, namely "housing price", "housing affordability", "mortgage interest rates", "value stability", "economic efficiency of the project", and "satisfaction of demand". The highest significance is given to "housing affordability" $(q=0.271)$. Figure 6 depicts efficiency indexes of the projects in the economic-sustainability dimension. It can be observed that the highest-ranked projects are A4, A7, and A1. The best-ranked project is in Latvia and reflects high affordability and value for money.

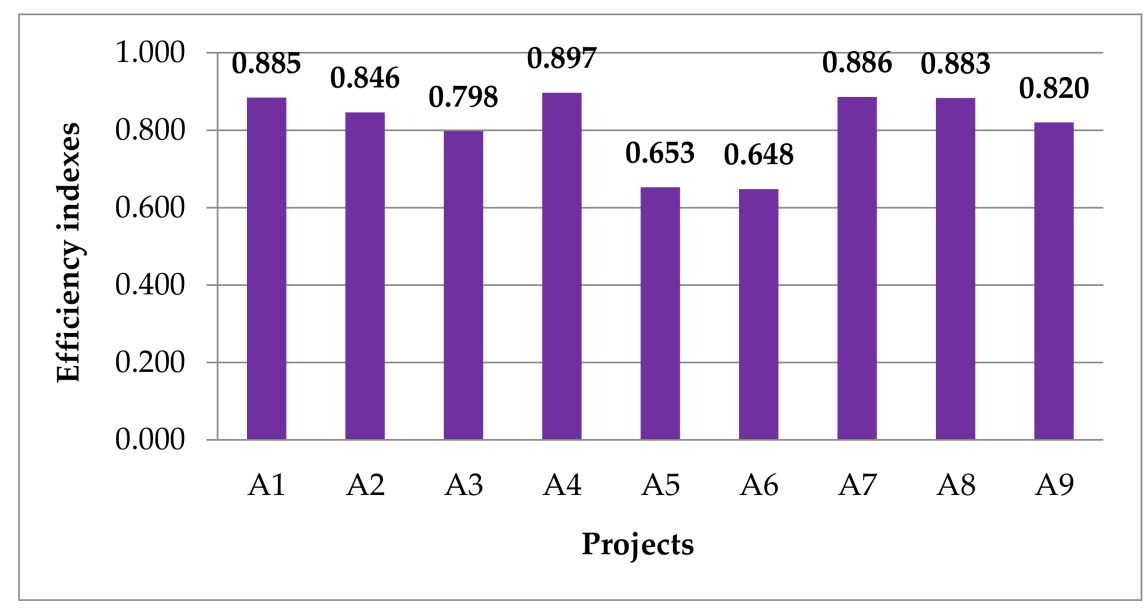

Figure 6. Efficiency of the residential projects in the economic-sustainability dimension.

In the final step of the analysis, projects have been ranked according to all sustainability dimensions, taking into account the significance of each dimension. In the previous research [21], experts considered environmental sustainability as more significant than the other two dimensions $(q=0.486)$. Not surprisingly, higher rank was also assigned to the economic dimension $(q=0.268)$ as economic issues are a priority in transitional countries such as the Baltic States. Notwithstanding, the social dimension was also considered as important $(q=0.246)$.

Final efficiency indexes obtained by the SAW method are presented in Figure 7. The Estonian project A9 has received the highest rank in all dimensions of sustainability. It is followed by the Lithuanian project A1. The Estonian project A8 takes third place. The lowest rankings have been received by Latvian projects A4 and A5. 


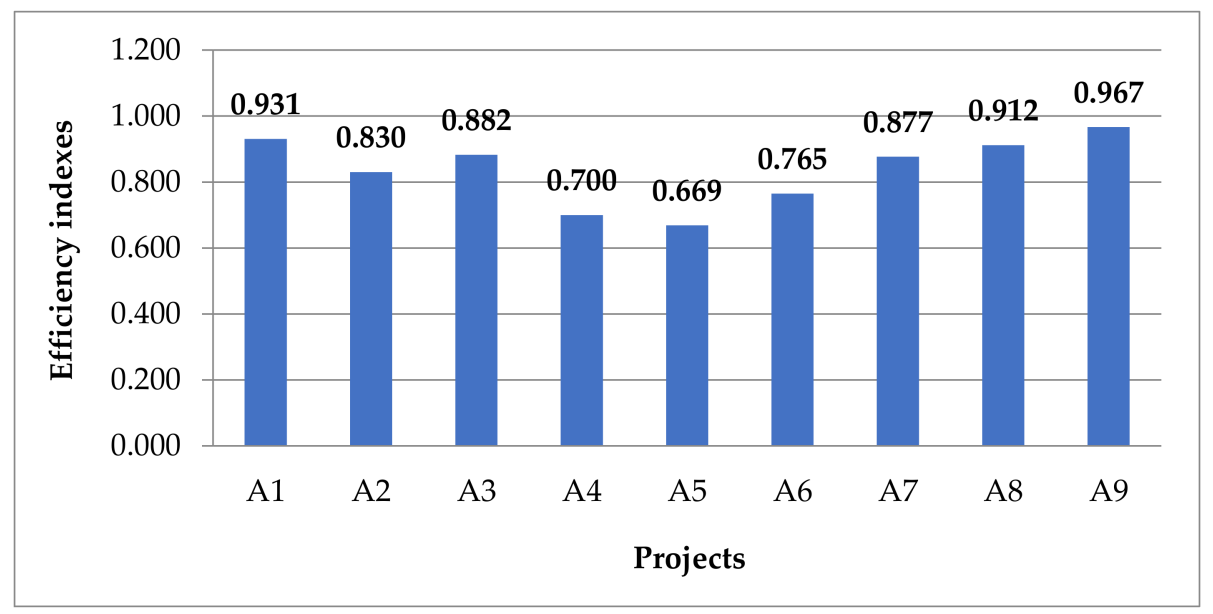

Figure 7. Overall sustainability ranking of the residential projects.

\subsection{Recommendations}

The present research suggests some new recommendations supplementing the previous research on sustainability indicators [21]:

1. An integrated sustainability assessment should simultaneously consider all three dimensions of sustainability (environmental, social, and economic). Therefore, it is recommended to use multiple-criteria assessment-based frameworks that allow for the comparison of residential projects according to different, usually conflicting, significance-sustainability indicators. The research follows criticism by other authors [10] that the currently used tools (i.e., BREEAM) ignore some of the economic and social aspects. The first residential building in the Baltic States which has been granted a BREEAM international sustainable building certificate (A6) has not been ranked as the best project as it has significant weaknesses in other sustainability aspects not included in the BREEAM methodology, i.e., economic and social indicators.

The integrated framework proposed by the authors can be used for the sustainability assessment of the other residential projects in the Baltic States to monitor and shape housing policy towards sustainable development.

2. Energy and atmosphere considerations as well as the selection of environmentally friendly materials are among the top priorities of the new residential projects in the Baltic States. Therefore, developers are encouraged to build new energy-efficient residential buildings from environmentally friendly, reused, and/or recycled materials. One of the alternatives could be the development of multi-storey wooden residential buildings. Professionals state that the age of multi-storey wooden buildings has begun. This movement of the construction of multi-storey wooden buildings is transnational and being implemented in the European Union and worldwide, i.e., in Canada, Australia, and the United States. In Europe and North America, the number of multi-storey wooden buildings is constantly increasing, especially in Scandinavian countries (Sweden, Norway, and Finland). Wood may be the most environmentally friendly material available for building dwellings or businesses. A building with $1 \mathrm{~m}^{3}$ of wood stores 1 ton of $\mathrm{CO}_{2}$.

3. From the economic point of view, new residential projects should be affordable, and from the social perspective, infrastructure efficient in respect to public transportation and access to the most important public amenities (schools, kindergartens, healthcare institutions, etc.). Therefore, residential projects in already developed areas of cities are preferred. One of the options is the regeneration of deteriorated properties and the development of new multifunctional projects, including reconstruction of old buildings into new, quality premises. 
4. The analysis has revealed that new residential projects in Estonia have been ranked higher compared to projects implemented in Lithuania and Latvia. Good Estonian practices could be transferred to these countries. In Lithuania, it is recommended to use more environmentally friendly materials (e.g., wood instead of concrete and steel) and to implement more technological and design innovations, including low-energy heating solutions, use of smart technologies, and increased functionality of apartments. For Latvia, it is recommended to construct buildings with higher energy efficiency and to ensure adequate infrastructure while choosing a location. For all three Baltic States, it is recommended to follow all the dimensions of sustainability. The developed framework of indicators could be used as a background in this case.

5. The Baltic States can adopt sustainable residential construction practices from other developed countries in the European Union and worldwide. However, new sustainable residential projects should suit the local context, depending on the culture, legislation, policy, stakeholders, practices, and institutions.

\section{Conclusions}

A multiple-criteria sustainability assessment of residential projects is useful for all the target groups to provide information on the sustainability of the projects as well as to allow them to be ranked according to different and often conflicting criteria. Buyers (households) can assess and more easily select their future apartments from different projects. Developers can assess the sustainability of their projects in general, find competitive advantages, and use this knowledge for future projects. Public institutions and communities can see the bigger picture of new residential-housing developments in the context of sustainable development.

This case study for the Baltic States has revealed that none of the projects is leading in all categories of sustainability. However, each project has its own strengths. Overall assessment of the projects with the SAW method has revealed that Estonian project A9 (Meerhof 2.0) has received the highest rank in all dimensions of sustainability. It has also been ranked as the best one in the "Materials and waste management", "Indoor environmental quality", "External pollution considerations", and "Innovation and design process considerations" environmental-sustainability categories. Lithuanian project A1 (Žalgirio namai 135) has been ranked as the second best and received the highest ranking in the "Energy and atmosphere considerations" (mostly due to high energy class) environmental-sustainability category and "Accessibilities" social-sustainability category. Estonian project A8 (Vibu 4/2) takes third place mostly due to having the highest score in the social-sustainability dimension. The Latvian projects received lower rankings; however, project A6 (Felicity Apartments) has been ranked the second-best project in the "Materials and waste management" (it has BREEAM certificate) environmental category, and project A4 (Domino) has been ranked the best one in the social-sustainability dimension.

In the present research, some limitations exist which should be solved in future studies. First, a small number of experts have participated in the estimation of qualitative indicators. Different groups of experts from different specialties could participate in refining the qualitative scores. Second, the proposed sustainability assessment framework is based on the SAW method. In future research, the authors will use other multiple-criteria methods to verify the obtained results and compare the findings with the existing sustainability-assessment tools (e.g., BREEAM).

Supplementary Materials: The following are available online at http:/ /www.mdpi.com/2071-1050/10/5/1387/s1, Table S1: Description of the sustainability indicators, Table S2: Normalized, weighted decision-making matrix and efficiency indexes (all categories), Table S3: Normalized, weighted decision-making matrix and efficiency indexes (environmental sustainability dimension), Table S4: Normalized, weighted decision-making matrix and efficiency indexes (social sustainability dimension), Table S5: Normalized, weighted decision-making matrix and efficiency indexes (overall ranking). 
Author Contributions: Laura Tupenaite and Arturas Kaklauskas researched, summarized literature and designed the methodology; Jurga Naimaviciene performed residential market research in the Baltic States; Jurga Naimaviciene and Loreta Kanapeckiene collected data on residential projects in Lithuania; Ineta Geipele and Linda Kauskale collected data on residential projects in Latvia; Irene Lill collected data on residential projects in Estonia; Laura Tupenaite performed calculations; and all of the authors contributed to discussion of results and recommendations, conclusions and the writing of the paper.

Acknowledgments: The present research has partly been financed under the EU project "Sustainable High-Rise Buildings Designed and Constructed in Timber" (HiTimber). Project No: 2017-1-DK-01-KA203-034242. Funds have been received to cover the costs for open-access publishing. Institutional research funding from the Estonian Ministry of Education and Research IUT1-15 “Nearly-zero energy solutions and their implementation on deep renovation of buildings" has also been used for this project.

Conflicts of Interest: The authors declare no conflicts of interest.

\section{References}

1. World Commission on Environment and Development. Our Common Future. 1987. Available online: http:/ / www.un-documents.net/our-common-future.pdf (accessed on 10 January 2018).

2. Turcu, C. Re-thinking sustainability indicators: Local perspectives of urban sustainability. J. Environ. Plan. Manag. 2013, 56, 695-719. [CrossRef]

3. Dumreicher, H.; Kolb, B. Place as a social space: Fields of encounter relating to the local sustainability process. J. Environ. Manag. 2008, 87, 317-328. [CrossRef] [PubMed]

4. Maliene, V.; Malys, N. High-quality housing-A key issue in delivering sustainable communities. Build. Environ. 2009, 44, 426-430. [CrossRef]

5. Ding, G.K.C. Sustainable construction-The role of environmental assessment tools. J. Environ. Manag. 2008, 86, 451-464. [CrossRef] [PubMed]

6. European Commission (EC). Energy Roadmap 2050; European Commission: Brussels, Belgium, 2011. Available online: https: / ec.europa.eu/energy/sites/ener/files/documents/2012_energy_roadmap_2050_en_0.pdf (accessed on 10 January 2018).

7. Mateus, R.; Braganca, L. Sustainability assessment and rating of buildings: Developing the methodology SBToolPT-H. Build. Environ. 2011, 46, 1962-1971. [CrossRef]

8. Zhang, X.; Wu, Y.; Shen, L.; Skitmore, M. A prototype system dynamic model for assessing the sustainability of construction projects. Int. J. Proj. Manag. 2014, 32, 66-76. [CrossRef]

9. Ali, H.H.; Al Nsairat, S.F. Developing a green building assessment tool for developing countries e case of Jordan. J. Build. Environ. 2009, 44, 1053-1064. [CrossRef]

10. Drejeris, R.; Kavolynas, A. Multi-criteria evaluation of building sustainability behavior. Procedia Soc. Behav. Sci. 2014, 110, 502-511. [CrossRef]

11. ALwaer, H.; Clements-Croome, D.J. Key performance indicators (KPIs) and priority setting in using the multi-attribute approach for assessing sustainable intelligent buildings. J. Build. Environ. 2010, 45, 799-807. [CrossRef]

12. Mulliner, E.; Smallbone, K.; Maliene, V. An assessment of sustainable housing affordability using a multiple criteria decision making method. Omega 2013, 41, 270-279. [CrossRef]

13. Mulliner, E.; Malys, N.; Maliene, V. Comparative analysis of MCDM methods for the assessment of sustainable housing affordability. Omega 2016, 59, 146-156. [CrossRef]

14. Yu, W.; Li, B.; Yang, X.; Wang, Q. A development of a rating method and weighting system for green store buildings in China. Renew. Energy 2015, 73, 123-129. [CrossRef]

15. Nilashi, M.; Zakaria, R.; Ibrahim, O.; Majid, M.Z.A.; Zin, R.M.; Chugtai, M.W.; Abidin, N.I.Z.; Sahamir, S.R.; Yakubu, D.A. A knowledge-based expert system for assessing the performance level of green buildings. Knowl. Based Syst. 2015, 86, 194-209. [CrossRef]

16. Markelj, J.; Kuzman, M.K.; Grošelj, P.; Zbašnik-Senegačnik, M. A simplified method for evaluating building sustainability in the early design phase for architects. Sustainability 2014, 6, 8775-8795. [CrossRef]

17. Chandratilake, S.R.; Dias, W.P.S. Sustainability rating systems for buildings: Comparisons and correlations. Energy 2013, 59, 22-28. [CrossRef]

18. Viteikiene, M.; Zavadskas, E.K. Evaluating the sustainability of Vilnius city residential areas. J. Civ. Eng. Manag. 2007, 13, 149-155. 
19. Zavadskas, E.K.; Cavallaro, F.; Podvezko, V.; Ubarte, I.; Kaklauskas, A. MCDM assessment of a healthy and safe built environment according to sustainable development principles: A practical neighborhood approach in Vilnius. Sustainability 2017, 9, 702. [CrossRef]

20. Nuuter, T.; Lill, I.; Tupenaite, L. Comparison of housing market sustainability in European countries based on multiple criteria assessment. Land Use Policy 2015, 42, 642-651. [CrossRef]

21. Tupenaite, L.; Lill, I.; Geipele, I.; Naimaviciene, J. Ranking of Sustainability Indicators for Assessment of the New Housing Development Projects: Case of the Baltic States. Resources 2017, 6, 55. [CrossRef]

22. Huang, I.B.; Keisler, J.; Linkov, I. Multi-criteria decision analysis in environmental sciences: Ten years of applications and trends. Sci. Total Environ. 2011, 409, 3578-3594. [CrossRef] [PubMed]

23. Cegan, J.C.; Filion, A.M.; Keisler, J.M.; Linkov, I. Trends and applications of multi-criteria decision analysis in environmental sciences: Literature review. Environ. Syst. Decis. 2017, 37, 123-133. [CrossRef]

24. MacCrimmon, K.R. Decision Making among Multiple-Attribute Alternatives: A Survey and Consolidated Approach; RAND Memorandum, RM-4823-ARPA; Rand Corp: Santa Monica, CA, USA, 1986.

25. Podvezko, V. The Comparative Analysis of MCDA Methods SAW and COPRAS. Inz. Ekon. Eng. Econ. 2011, 22, 134-146. [CrossRef]

26. State Enterprise Centre of Registers. Baltic Review 2016; State Enterprise Centre of Registers: Vilnius, Lithuania, 2016.

27. EIKA. Žalgirio 135. Available online: http:/ / www.eika.lt/en/zalgirio-135/ (accessed on 15 February 2018).

28. MG Valda. Lighthouse II. Available online: http://mgvalda.lt/projektas/lighthouse-ii/ (accessed on 15 February 2018).

29. HANNER. Žvèryno Namai. Available online: http://hanner.lt/en/properties/zveryno-namai/ (accessed on 15 February 2018).

30. City Real Estate. Domino. Available online: https://www.cityreal.lv/en/new-projects/projekts/domino/ ?no_cache=1 (accessed on 10 December 2017).

31. SIA Pillar Management. Miera Park House. Available online: http://www.pillar.lv/lv/sale/projects/9 (accessed on 10 December 2017).

32. SIA "Domuss". 'Felicity Apartments', E.Birznieka-Upīša 13 Rīga. Available online: http://www. domuss.lv/lv/jaunie_projekti/dzivokli/039felicity_apartments039_e.birznieka-upisa_13_riga/ (accessed on 10 December 2017).

33. MERKO. Noblessner Home Port. Available online: http://group.merko.ee/en/projekt/noblessnerdevelopment-staapli-3-4-8-12-residential-and-business-buildings/ (accessed on 10 December 2017).

34. YIT. Vibu 2/4. Available online: https://www.yit.ee/en/housing-development/tallinn/pohja-tallinn/vibu24 (accessed on 10 December 2017).

35. Meerhof 2.0. Available online: http://www.metro.ee/meerhof/en/ (accessed on 10 December 2017). 